\title{
VAI TRÒ PHẪU THUẬT NẠO HẠCH TRONG ĐIỀU TRI UNG THƯ PHỔI KHÔNG TẾ BÀO NHỎ
}

\author{
Đố Kim Quế*
}

\section{TÓM TẮT}

Trong thời gian 10 năm từ năm 2004 tới năm 2014có 94 bệnh nhân ung thư phổi không tế bào nhỏ có hạch trung thất đã được phẫu thuật tại bệnh viện Thống Nhất. 78 trường hợp cắt 1 thùy phổi chiếm tỉ lệ $83 \%, 2$ trường hợp cắt 2 thùy phổi chiếm tỉ lệ $2,1 \%$, cắt toàn bộ 1 bên phổi trong 3 trường hợp chiếm tỉ lệ $3,2 \%, 3$ trường hợp mổ nội soi cắt thùy phổi chiếm tỉ lệ $3,2 \%, 8$ trường hợp mổ thám sát sinh thiết u và hạch trung thất chiếm tỉ lệ $8,5 \%$. Tất cả 94 bệnh nhân đều được hóa trị bổ trợ với phác đồ có platinum.

62 trường hợp phát hiện có hạch trung thất trước mổ trên chụp vi tính cắt lớp chiếm tỉ lệ $66,0 \% .42$ trường hợp hạch trung thất phát hiện có tế bào ung thư di căn trên mô bệnh học chiếm tỉ lệ 44,7\%.

Kết quả sớm cho thấy không có tử vong do phẫu thuật. 1 trường hợp chảy máu sau mổ chiếm tỉ lệ $1,1 \%$. Xẹp phổi do tắc đàm 1 trường hợp, tràn khí màng phổi kéo dài 2 trường hợp.

Thời gian sống thêm trung bình là 36 tháng, thời gian sống thêm không bệnh trung bình là 30,4 tháng. Tỉ lệ sống thêm 5 năm là $19,1 \%$. Có sự khác biệt giữa nhóm bệnh nhân có hạch N2 có tế bào ung thư di căn và nhóm hạch N2 không có tế bào ung thư di căn về thời gian sống thêm 5 năm lần lượt là $14,3 \%$ và $23,1 \%$.

\section{SUMARY:}

ROLE OF LYMPH NODE DISSECTION IN SURGICAL TREATMENT FORNON SMALL CELL LUNG CANCER
During 10 years from 2004 to 2014 we treat for 94 patients who have NSCLC with N2 were operated in Thong Nhat hospital. Staging was based on AJCC 1997.

Primary outcomes are mortality rate, morbidities. Over all survial, disease freed survival, 5 years survival.

All patients underwent lobectomy or pneumonectomy with lymph node dissection. Adjuvant chemotherapy with platinum based regimen were given for all patients.

78 patients $(83,0 \%)$ underwent lobectomy, 2 patients $(2,1 \%)$ underwent bilobectomy, 3 patients $(3,2 \%)$ underwent pneumonectomy, 3 patients underwent endoscopic lobecthomy, 8 patients $(8,5 \%)$ underwent explorative operation. 62 cases $(66,0 \%)$ have mediastinal lymph node on $\mathrm{CT}$ scan before operation. 42 cases $(44,7 \%)$ with $\mathrm{N} 2$ are positive on histologic findings.

No mortality, 1 cases had post operation bleeding, 1 case had atelectasia, 2 cases had prolonged air leak.

5 years survival is $19,1 \%$, in group with $\mathrm{N} 2$ positive is $14,3 \%$ and in group $\mathrm{N} 2$ negative is $23,1 \%$

Thorax CT scan have low sensitives. Positive N2 rate is low among NSCLC N2

\footnotetext{
* Bệnh viện Thống Nhất

Nguoòi chịu trách nhiệm khoa học: PGS.TS. Đỗ Kim Quế Ngày nhận bài: 10/02/2017 - Ngày Cho Phép Đăng: 10/03/2017

Phản Biện Khoa học: PGS.TS. Đặng Ngọc Hùng
} GS.TS. Bùi Đức Phú 
detected

on

operation.

Lobectomy/pneumonectomy with lymph node dissection should be done for patient with N2 NSCLC detected on operation.

Tù khoá: Ung thư phổi không tế bào nhỏ, hoá trị bổ trợ, Resectable NSCLC, adjuvant chemotherapy.

\section{I. ĐẶT VẤN ĐỀ}

Ung thư phổi là một trong những ung thư thường gặp nhất ở cả nam lẫn nữ và là nguyên nhân gây tử vong hàng đầu trong các bệnh ung thư. Hiện nay tần suất ung thư phổi có khuynh hướng gia tăng tại các nước đang phát triển trong đó có Việt Nam. Theo báo cáo của Ủy ban phòng chống ung thư quốc gia Việt Nam tỉ lệ ung thư phổi ở nam giới là 30,7 / 100.000 dân và $6,7 / 100.000$ dân ở nữ giới. Hàng năm ở Việt Nam có khoảng 21.800 trường hợp ung thư phổi mới mắc và khoảng 19.500 trường hợp tử vong.

Theo số liệu của Globocan 2012, ước tính trên thế giới có khoảng 1.800.000 trường hợp ung thư mới phát hiện và có khoảng 1.600.000 trường hợp tử vong.

Tại Mỹ trong năm 2011 có 226.160 trường hợp ung thư phổi mới phát hiện, và trên 180.340 trường hợp ung thư phổi đã bị tử vong. [1, 4]

Mặc dù phẫu thuật hiện nay vẫn là phương pháp điều trị chính trong ung thư phổi, tuy nhiên đa số các trường hợp ung thư phổi được phát hiện ở giai đoạn muộn không còn chỉ định điều trị phẫu thuật triệt để. Theo Socinski tại Mỹ hơn 40\% các trường hợp ung thư phổi được phát hiện ở giai đoạn IV đã có di căn xa, 40 - $70 \%$ những trường hợp ung thư phổi ở giai đoạn I - III sau điều trị phẫu thuật và / hoặc xạ trị có tái phát tại chỗ xuất hiện di căn xa.[24, 26]

Với bệnh nhân ung thư phổi không tế bào nhỏ có hạch trung thất chiến lược điều trị còn đang được bàn cãi. Một số nghiên cứu cho thấy phẫu thuật cắt thùy phổi cho kết quả không tốt hơn hóa xạ đồng thời. Tuy nhiên, có những nghiên cứu cho thấy cho kết quả tốt hơn, nhất là những trường hợp hạch trung thất không có tế bào ung thư di căn. Hóa trị tân bổ trợ cũng cũng là một cách tiếp cận cho những bệnh nhân ung thư phổi không tế bào nhỏ có di căn hạch trung thất. [17, 19, 20]

Mục tiêu nghiên cứu của chúng tôi nhằm đánh giá giá trị của phẫu thuật nạo hạch trong điều trị ung thư phổi không tế bào nhỏ, và kết quả ngắn hạn và dài hạn của ung thư phổi có hạch trung thất được điều trị phẫu thuật.

\section{II. ĐỐI TƯợNG VÀ PHƯƠNG PHÁP NGHIÊN CÚU:}

\section{1. Đối tuọng nghiên cúu:}

Toàn bộ bệnh nhân ung thư phổi không tế bào nhỏ được điều trị phẫu thuật tại bệnh viện Thống nhất trong thời gian từ tháng 2004 tới 2014.

\subsection{Phương pháp:}

Nghiên cứu tiền cứu mô tả cắt dọc.

Tiêu chuẩn chọn bệnh: Ung thư phổi không tế bào nhỏ đã được phẫu thuật và có chẩn đoán giải phẫu bệnh lý.

- Chẩn đoán hình ảnh học:

○ CT scan trước phẫu thuật. Đánh giá kích thước khối u, hạch di căn.

- Chẩn đoán giải phẫu bệnh:

○ Nội soi phế quản, khối u, hạch rốn phổi và hạch trung thất sau phẫu thuật.

- Chẩn đoán giai đoạn:

- Dựa trên kết quả CT scan ngực có cản quang, nội soi phế quản hoặc đánh giá trong mổ và kết quả giải phẫu bệnh sau mổ. 
Đánh giá giai đoạn ung thư phổi theo phân giai đoạn năm 1997 của Ủy ban chống ung thư hoa kỳ (AJCC) và liên hiệp chống ung thư quốc tế (UICC).

\section{Phương pháp điều trị:}

- Phẫu thuật:

○ Cắt thùy phổi

○ Cắt 2 thùy phổi

○ Cắt toàn bộ 1 phổi

○ Thám sát sinh thiết.

○ Nạo hạch được thực hiện cho toàn bộ các hạch phát hiện khi mổ.

\section{Đánh giá kết quả:}

- Kết quả phẫu thuật:

\section{KẾT QUẢ NGHIÊN CÚU}

Trong thời gian 10 năm tháng từ 2004 đến 2014 chúng tôi đã điều trị phẫu thuật cho 94 trường hợp ung thư phổi không tế bào nhỏ có hạch N2.

3.1.Tuổi và giới: Có 73 nam và 21 nữ

Tuổi trung bình: 65,25 , nhỏ nhất là 35 và lớn nhất là 80

\subsection{Thói quen hút thuốc:}

$92 \%$ bệnh nhân ung thư phổi có hút thuốc lá, trong đó tỉ lệ này ở nam là $100 \%$ và nữ là $63 \%$.

Thời gian hút thuốc dài nhất là 30 năm, trung bình lượng thuốc hút mỗi ngày 30 điếu.

\subsection{Kết quả CT scan ngục có cản quang.}

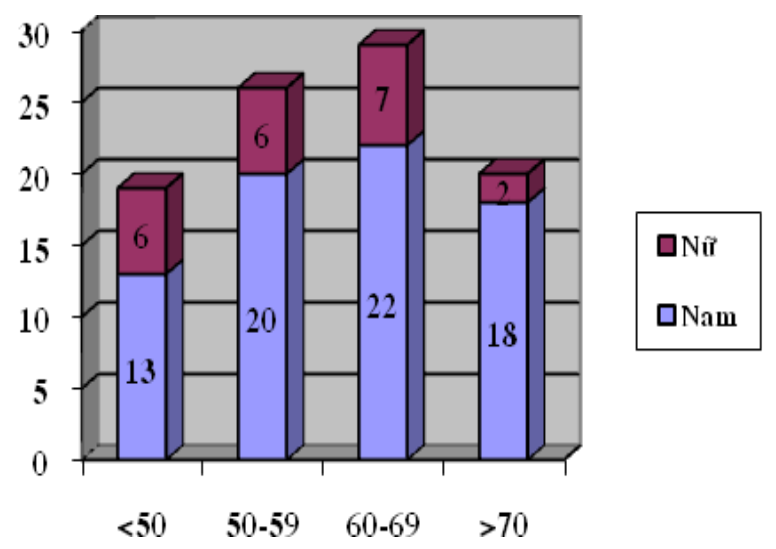

\section{Bảng 3.1:}

Đặc điểm CT scan lồng ngục

Khối u

$$
<3 \mathrm{~cm}
$$

$3-5 \mathrm{~cm}$

$>5 \mathrm{~cm}$

Hạch rốn phổi

Hạch trung thất

Mức nước hơi

Tràn dịch màng phổi

Xẹp phổi
○ Tốt: Không có biến chứng trong và sau phẫu thuật.

○ Trung bình: Có biến chứng nhẹ: Nhiễm trùng vết mổ, xẹp phổi sau mổ.

○ Xấu: Có biến chứng nặng sau mổ: Chảy máu nhiều sau mố cần mổ lại, Dò phế quản, mủ màng phổi.

○ Tử vong.

- Kết quả lâu dài:

○ Thời gian tái phát:

- Tái phát tại chỗ.

- Di căn xa.

Thời gian sống thêm toàn bộ, thời gian sống thêm không bệnh. 


\subsection{Kết quả nội soi phế quản}

Tất cả các trường hợp u phổi của chúng tôi đều được thực hiện nội soi phế quản với kết quả.

\section{Bảng 3.2:}

Kết quả nội soi phế quản

U nội phế quản

U chèn ép khí phế quản

Cây khí phế quản bình thường

Kết quả giải phẫu bệnh:

Ung thư tế bào tuyến

Ung thư tế bào vảy

Ung thư thư tế bào lớn

Dị sản, chuyển sản

Viêm mạn tính
Số $B N$ 28

13

53

42

2

0

6

44
$\%$

29.8

13.8

56.4

2.1

0.0

6.3

46.8

\section{5. Đặc điểm giải phẫu bệnh lý sau mổ:}

Tất cả các trường hợp phẫu thuật đều được gửi giải phẫu bệnh lý xác định loại ung thư và mức độ xâm lấn và di căn.

Bảng 3.3 Đặc điểm mô học:

Đặc điểm giải phẫu bệnh

Ung thư tế bào lớn

Ung thư biểu mô tế bào vảy

Ung thư biểu mô tuyến
Số $B N$

4

10

80
$\%$

10.7

85.1

Bảng 3.4 Đánh giá hạch trung thất:

\begin{tabular}{lcc} 
Hạch trung thất & Số BN & $\%$ \\
\hline CT scan ngực & 62 & 66,0 \\
Phẫu thuật & 94 & 100,0 \\
GPBL & 42 & 44,7
\end{tabular}




\subsection{Chẩn đoán giai đọ̣n sau mổ:}

Chúng tôi dựa trên hệ thống phân giai đoạn ung thư phổi của hiệp hội chống ung thư Hoa kỳ năm 1997.

Bảng 3.5: Chẩn đoán giai đoạn ung thu phổi:

\begin{tabular}{lcc} 
Giai đoạn & Só $\boldsymbol{B} \boldsymbol{N}$ & $\boldsymbol{\%}$ \\
\hline IIA & 4 & 4.2 \\
IIB & 22 & 23.4 \\
IIIA & 60 & 63.9 \\
IIIB & 6 & 6.4 \\
IV & 2 & 2.1
\end{tabular}

\subsection{Phưong pháp điều trị:}

Phẫu thuật được áp dụng cho tất cả 94 trường hợp với gây mê nội phế quản chọn lọc.

Đường mổ ngực sau bên cho tất cả các trường hợp, trừ 4 trường hợp cắt $\mathrm{u}$ thùy giữa phổi.

Phẫu thuật nội soi lồng ngực được áp dụng cho 3 trường hợp.

Bảng 3.6: Các phuoong pháp phẫu thuật.

\begin{tabular}{lcc} 
Phuơng pháp phẫu thuật & Số $\boldsymbol{B N}$ & $\%$ \\
\hline Nội soi lồng ngực cắt thùy phổi & 3 & 3.2 \\
Cắt thùy phổi & 78 & 83.0 \\
Cắt 2 thùy phổi & 2 & 2.1 \\
Cắt toàn bộ phổi trái & 3 & 3.2 \\
Thám sát & 8 & 8.5
\end{tabular}

\subsection{Kết quả phẫu thuật:}

Bảng 3.7 Kết quả điều trị ngắn hạn:

\begin{tabular}{lcc} 
Kết quả điều trị ngắn hạn & Số $\boldsymbol{B N}$ & $\%$ \\
\hline Tử vong & 0 & 0.0 \\
Nhiễm trùng khoang màng phổi & 0 & 0.0 \\
Xẹp phổi & 1 & 1.1 \\
Tràn dịch khí màng phổi & 2 & 2.1 \\
Nhiễm trùng vết mổ & 0 & $0.0 \%$
\end{tabular}


Bảng 3.8 Kết quả điều trị lâu dài.

\begin{tabular}{lcc} 
Kết quả điều trị lâu dài & Số $\boldsymbol{B N}$ & \% \\
\hline Tử vong trong 6 tháng & 4 & 4.2 \\
Tử vong trong 1 năm & 9 & 9.6 \\
Tái phát u trong lồng ngực & 2 & 2.1 \\
Di căn xa & 4 & 4.2
\end{tabular}

Bảng 3.9 Thời gian sống thêm toàn bộ 5 năm.

\begin{tabular}{|l|c|c|}
\hline Nhóm bệnh & Số $\boldsymbol{B N}$ & \% \\
\hline Hạch N2 có ung thư di căn & 6 & 14,3 \\
\hline Hạch N2 không có ung thư di căn & 12 & 23,1 \\
\hline Chung & 18 & 19,1 \\
\hline
\end{tabular}

\section{BÀN LUẬN:}

Ung thư phổi là một bệnh lý khá thường gặp, đa số các trường hợp vào viện ở giai đoạn muộn, trong nghiên cứu này chúng tôi thu thập các trường hợp có hạch N2 và được phẫu thuật tại khoa ngoại bệnh viện Thống nhất. Theo các báo cáo trong $\mathrm{y}$ văn, phần lớn các trường hợp đều được phát hiện ở giai đoạn muộn. Trong nghiên cứu này của chúng tôi có tới gần $70 \%$ các trường hợp ung thư phổi ở giai đoạn III và IV, mặc dù khoa chúng tôi chỉ nhận những trường hợp còn có khả năng điều trị phẫu thuật.

Chẩn đoán ung thư phổi chủ yếu dựa trên CT scan ngực có cản quang phối hợp với nội soi phế quản sinh thiết hoặc trải tế bào phế quản. Chúng tôi kết hợp với bệnh viện Phạm Ngọc Thạch làm các xét nghiệm chẩn đoán trước mổ.

Chẩn đoán chính xác giai đoạn ung thư phổi có ý nghĩa rất quan trọng trong việc chọn lựa phương pháp điều trị cũng như dự hậu cho người bệnh.[2, 9, 25] Tại bệnh viện chúng tôi
$100 \%$ các trường hợp ung thư phổi được làm CT scan ngực và nội soi phế quản nên việc đánh giá giai đoạn ung thư phổi có độ nhậy và độ chuyên cao.

Gần $50 \%$ các trường hợp nội soi phế quản cho kết quả dương tính về tế bào học, chúng tôi chỉ gặp 2 trường hợp chẩn đoán tế bào học qua nội soi phế quản là ung thư nhưng kết quả giải phẫu bệnh sau khi phẫu thuật là viêm phổi hoại tử và u nấm phổi.

Chúng tôi đánh giá giai đoạn cũng như kết quả điều trị dựa trên kết quả CT scan, theo Mac Manus [12] thì tỉ lệ đáp ứng sẽ chính xác hơn và cao hơn nếu đánh giá dựa trên PET, tuy nhiên phương tiện này còn đắt tiền và không phải trung tâm nào cũng thực hiện được.

Trong nghiên cứu của mình với 74 bệnh nhân Mac Manus [12] ghi nhận tỉ lệ có đáp ứng trên CT scan là $64 \%$ so với PET là $84 \%$. Và tỉ lệ không đáp ứng và bệnh tiến triển là $27 \%$ trên $\mathrm{CT}$ scan so với PET chỉ còn $17 \%$. [27] 
Theo Sebastian và cộng sự[21] 6,1\% bệnh nhân ung thư phổi không tế bào nhỏ T1 có hạch $\mathrm{N} 2$, trong đó $69 \%$ các trường hợp khối u nằm ở trung tâm. Vị trí hạch số $7,4,5$ là những nơi thường bị tổn thương nhất với tỉ lệ $37 \%$ và $31 \%$.

Phẫu thuật được chúng tôi áp dụng cho tất cả các trường hợp. Phẫu thuật nội soi lồng ngực cắt thùy phổi đã được chúng tôi áp dụng cho 3 trường hợp với kết quả tốt. Hiện nay phẫu thuật cắt thùy phổi với video hỗ trợ đang rất được ưa chuộng tại các trung tâm lớn.

Phẫu thuật cắt thùy phổi là phương pháp chính trong điều trị ung thư phổi, trường hợp khối u xâm lấn phế quản thùy lân cận có thể phải áp dụng phẫu thuật cắt bỏ 2 thùy phổi hoặc cắt xử toàn bộ một bên phổi. Đa số các tác giả thống nhất cắt thùy phổi là đủ rộng khi điều trị ung thư phổi. $[15,16]$

Một vấn đề cần lưu ý trong xử trí ung thư phổi là tình trạng di căn sang thùy lân cận, Theo Fontain những trường hợp này xem như là di căn xa. Chúng tôi có gặp 2 trường hợp và cả 2 trường hợp chỉ được phát hiện khi phẫu thuật.

Phẫu thuật cắt thùy phổi là một phương pháp an toàn với tỉ lệ tử vong thấp từ $1-5 \%$. Trong nghiên cứu của chúng tôi không có tử vong, $3.2 \%$ các trường hợp có biến chứng nhẹ và được xử trí đơn giản.

Về mặt giải phẫu bệnh lý chúng tôi nhận thấy tỉ lệ ung thư biểu mô tuyến có tỉ lệ ngày càng cao. 2 trường hợp ung thư phổi tế bào nhỏ được chỉ định phẫu thuật khi nội soi phế quản không xác định được bản chất của khối u. Đây cũng là kết quả chung của các nghiên cứu trong và ngoài nước.

Về kết quả lâu dài của ung thư phổi tùy thuộc chủ yếu vào giai đoạn của bệnh khi được xử trí. Tỉ lệ sống 5 năm của ung thư phổi là 14,3 và $23,1 \%$ cho nhóm bệnh nhân có di căn hạch $\mathrm{N} 2$ và nhóm không có di căn hạch N2. Theo Misthos và cộng sự [14], tỉ lệ sống thêm 3 năm ở bệnh nhân có hạch N2 là $24 \%$ so với $38 \%$ ở nhóm khong có di căn hạch N2.

\section{KẾT LUẬN:}

5.1. Qua nghiên cứu 94 trường hợp ung thư phổi không tế bào nhỏ được điều trị phẫu thuật có nạo hạch tại bệnh viện Thống nhất chúng tôi rút ra một số kết luận:

5.2. Đa số ung thư phổi gặp ở người lớn tuổi có hút thuốc lá, ung thư biểu mô tuyến chiếm tỉ lệ cao tuyệt đối so với các dạng ung thư khác. Phần lớn các trường hợp ung thư tới viện ở giai đoạn muộn đã có hạch trung thất.

5.3. Khả năng phát hiện hạch trung thất của CT scan ngực chỉ đạt $66 \%$, tuy nhiên tỉ lệ hạch trung thất được phát hiện trong mổ có tế bào ung thư di căn chỉ chiếm 44,7\%

5.4. Phẫu thuật cắt thùy phổi và nạo hạch là phương pháp điều trị an toàn và hiệu quả cho những trường hợp còn có khả năng cắt $u$ ngay cả khi phát hiện có hạch N2 trong phẫu thuật.

\section{TÀI LIÊUU THAM KHẢO}

1. Besse B, Chevalier TL (2008). Adjuvant Chemotherapy for Non-Small-Cell Lung Cancer: A Fading Effect? Journal of Clinical Oncology 26(31):5014-5017.

2. Betticher DC, Schmitz SH, Totsch M, et al (2003). Mediastinal lymph node clearance after Docetaxel-Cisplatin Neoadjuvant chemotherapy is pronogtic of survival in patient with stage IIIA pN2 Non small cell lung cancer: A multicenter phase II trial. J Clin Oncol 21: 1752-1759. 
3. Bonomi P, Kim K, Fairclough D et al, (2000) Comparison of survival and quanlity of life in advanced non-small cell lung cancer patients treated with two dose levels of paclitaxel combined with cisplatin versus etoposide with cisplatin: results of an Eastern Cooperative Oncology Group trial. J Clin Oncol 18(3):623-631.

4. Hainaut P, Ma X, Lacas B, Tsao M et al. (2012). Lace bio pools analysis of the prognostic and predictive value of TP53 mutation in completely resected non small cell lung cancer. Abstract 1192PD ESMO.

5. Mac Manus MP, Hicks RJ, Mathews JP et al, (2003). Positron Emission tomography is superior to computed tomography scanning for response-assessment after radical radiotherapy odr chemotherapy in patients with non-small cell lung cancer. J Clin Oncol. 21:1285-1292

6. Misthos P, Sepsas E, Kokotsakis J, Skottis I, Lioulias A. (2008)The Significance of OneStation N2 Disease in the Prognosis of Patients With Nonsmall-Cell Lung Cancer. Ann Thorac Surg 86:1626-31.

7. Ohta Y, Oda M, Wu J, Tsunezuka Y, Hiroshi M, Nonomura A, Watanabe G. (2001) Can tumors size be a guide for limitted sugical intervention in patients with peripheral NSCLC. J Thorac Cardiovasc Surg 122: 900 - 906.

8. Okada M, Yamagishi H, Satake S, Matsuoka H, Miyamoto Y, et al. (2000) Suvival related to lymph node involvement in lung cancer after sleeve lobectomy compared to pneumonectomy. J Thorac Cardiovasc Surg 119: $814-19$.

9. Patel MI, Wakelee HA. (2011). Adjuvant chemotherapy for early stage non-small cell lung cancer. 1(45):1-4.

10. Rinaldi M, Crino L, Scagliotti GV et al, (2000). A three weeks schedule of gemcitabine-cisplatin in advanced non-small cell lung cancer with two different cisplatin dose levels: A phase II randomized trial. Ann Oncol 11(10):1295-1300.

11. Sandler AB, Numunaitis J, Denham $C$ et al. (2000). PhaseIII trial of gemcitabine plus cisplatin versus cisplatin alone in patients with locally advanced or metastatic non-small-cell lung cancer. J Clin Oncol 18(1): 122-130

12. Schiller JH, Harrington D, Sandler A et al, (2000) Arandomized trial of four chemotherapy regimens in advanced nonsmall cell lung tumors. Proc Am Soc Clin Oncol 18:1a.

13. Sebastian A. Defranchi SA, Cassivi SD, Nichols FC, Allen MS, Shen KR, Deschamps C, Wigle DA. (2009) N2 Disease in T1 Non-Small Cell Lung Cancer. Ann Thorac Surg 88:924 -9.

14. Socinski MA (2003). A dressing the optimal duration of therapy in advanced, metastatic non small cell lung cancer. American society of clinical oncology p144-152

15. Takiguchi Y, Nagao K, Nishiwaki Y et al, (2000). The final results of a randomized phase III trial comparing irrinotecan and cisplatin with vindesine and cisplatin in advanced non-small cell lung cancer. Lung cancer 29(suppl 1):28.

16. Vesselle H, Pugley M, Vallieres E, Wood DE. (2002) The impact of fluorodeoxyglucose $\mathrm{F} 18$ positron-emission tomography on the sugical staging of NSCLC. J Thorac Cardiovasc Surg 124: 511-19. 